\title{
POTENTIODYNAMIC AND XPS STUDIES OF X10CrNi18-8 STEEL AFTER ETHYLENE OXIDE STERILIZATION
}

\author{
POTENCIODINAMIČNE IN XPS ANALIZE JEKLA X10CrNi18-8 PO \\ STERILIZACIJI Z ETILEN OKSIDOM
}

\author{
Witold Walke' ${ }^{1}$ Joanna Przondziono ${ }^{2}$ \\ ${ }^{1}$ Silesian University of Technology, Faculty of Biomedical Engineering, Ch. de Gaulle'a 66, 41-800 Zabrze, Poland \\ ${ }^{2}$ Silesian University of Technology, Faculty of Materials Engineering and Metallurgy, Krasińskiego 8, 40-019 Katowice, Poland \\ witold.walke@polsl.pl
}

Prejem rokopisa - received: 2013-11-14; sprejem za objavo - accepted for publication: 2014-05-09

doi:10.17222/mit.2013.281

\begin{abstract}
An innovative development in the treatment of heart, blood and vascular-system diseases using low-invasive techniques led to a development of new forms of tools (among other devices: cardiologic guide wires) made of the X10CrNi18-8 steel. The authors of this study made an attempt to evaluate the impact of one of the medical sterilisation methods, i.e., the ethylene oxide sterilisation of a wire made of the X10CrNi18-8 steel after electrochemical polishing and chemical passivation. One of the basic criteria for deciding about the suitability of a specific material for a vascular tool is the proper corrosion resistance in a blood environment. It is directly connected with the chemical composition of the surface layer. Therefore, an evaluation was made on the basis of pitting-corrosion tests and the tests of the chemical compositions of the surface layers by means of the XPS method. The samples were subjected to the tests before and after the ethylene oxide sterilisation. The obtained results explicitly prove that the chemical-passivation process of the X10CrNi18-8 steel improves its resistance to corrosion in a blood environment. The resistance is higher due to the creation of a thin passive layer, mainly built of $\mathrm{Fe}_{2} \mathrm{O}_{3}$ and $\mathrm{Cr}_{2} \mathrm{O}_{3}$ on the surface, which was proved during the XPS tests. Next, the sterilisation in ethylene oxide had a favourable influence on the electrochemical properties of the X10CrNi18-8 steel, irrespective of the way of surface preparation. The presence of the alloying elements in the oxidised form was also detected in the surface layer, contributing to the improvement of the corrosion resistance in contact with the blood.

Keywords: X10CrNi18-8 steel, EO sterilization, XPS, pitting corrosion
\end{abstract}

Razvoj inovativnih metod pri zdravljenju srca, kot tudi krvno-žilnih bolezni, z uporabo malo invazivnih tehnik je pripeljal do novih oblik orodij (med drugim tudi kardioloških uvajalnih žic), izdelanih iz jekla X10CrNi18-8. Avtorji te študije si prizadevajo oceniti vpliv ene od sterilizacijskih metod, to je sterilizacija žice, izdelane iz jekla X10CrNi18-8 z etilen oksidom, po elektrokemijskem poliranju in po kemijski pasivaciji. Eden od osnovnih meril, ki odločajo o primernosti določenega materiala za orodja za ožilja, je primerna korozijska obstojnost v krvi. Ta je neposredno povezana s kemijsko sestavo površinske plasti. Zato je bila izdelana ocena na podlagi preizkusov jamičaste korozije in analize sestave površine z XPS-metodo. Vzorci so bili preizkušeni pred sterilizacijo z etilen oksidom in po njej. Dobljeni rezultati so neposredno dokazali, da proces kemijske pasivacije jekla X10CrNi18-8 izboljša njegovo odpornost proti koroziji v okolju s krvjo. To je povezano z nastankom tanke pasivne plasti iz $\mathrm{Fe}_{2} \mathrm{O}_{3}$ in $\mathrm{Cr}_{2} \mathrm{O}_{3}$ na površini, kar je bilo dokazano z XPS-analizami. Sterilizacija in etilen oksid imata ugoden vpliv na elektrokemijske lastnosti jekla X10CrNi18-8, ne glede na način priprave površine. Na površini je bila odkrita prisotnost oksidiranih legirnih elementov, ki prispevajo k izboljšanju korozijske odpornosti pri stiku s krvjo.

Ključne besede: jeklo X10CrNi18-8, EO-sterilizacija, XPS, jamičasta korozija

\section{INTRODUCTION}

Cardiologic guide wires have an extremely important role in the success of a coronary intervention. It is believed that the success of such a treatment depends on the type and quality of a guide wire. The guide wire is the first to reach the area of atherosclerotic lesion and it passes through a narrowing, previously passing along a complicated route inside the vessels, e.g., coronary arteries. Quite frequently, it also has to pass through a lesion that is totally closed. Guide wires differ as far as their profile, flexibility and tip configuration are concerned. The market offers guide wires with a J-shaped tip or a straight tip for individual forming. The diameter of modern guide wires is within the range of $0.35-0.45$ $\mathrm{mm}$, and their length is within the range of 180-300 mm. These wires, due to their direct contact with the blood, must feature a proper set of electrochemical properties also determined by the conditions of medical sterilisation. ${ }^{1,2}$ An important issue in the process of forming guide-wire functional characteristics is the selection of the characteristics of the metallic material they are made of. ${ }^{3-5}$ Mechanical characteristics of the material are selected on the ground of biomechanical characteristics determined for individual forms of instruments, taking the anatomical load for each type of the system into consideration. A crucial issue for the cardiologic guide-wire functional characteristics is the proper method of the surface preparation. The restrictions arising from implementing a tool made of a metallic material in the blood and vascular system have made numerous researchers look for the ways of efficiently diminishing the influences of the body fluids on the metal corrosion. It results from the analysis of the subject-matter data that one of the main factors influencing the efficiency of a treatment is the guide- 
wire surface roughness. The significance of the surface-layer chemical composition cannot be neglected either. 6,7 One of the basic treatments increasing the corrosion resistance of steel in the environment of human blood is the chemical-passivation process. Therefore, the authors of this study attempted to make an evaluation of the influence of the surface treatment (electrochemical polishing and chemical passivation) of steel X10CrNi18-8 on the biotolerance in the environment of human blood under the conditions of sterilisation with ethylene oxide.

\section{EXPERIMENTAL WORK}

Samples made of steel X10CrNi18-8 in the form of a wire with a diameter of $1 \mathrm{~mm}$ were selected for the tests. The chemical composition of the steel is presented in Table 1.

Table 1: Chemical composition of $\mathrm{X} 10 \mathrm{CrNi18}-8$ steel in mass fractions, $w / \%$

Tabela 1: Kemijska sestava jekla X10CrNi18-8 v masnih deležih, $w / \%$

\begin{tabular}{|c|c|c|c|c|c|c|}
\hline Steel & $\mathrm{C}$ & $\mathrm{Mn}$ & $\mathrm{Si}$ & $\mathrm{P}$ & $\mathrm{S}$ & $\mathrm{Cr}$ \\
\hline X10CrNi18-8 & 0.08 & 0.91 & 0.68 & 0.028 & 0.001 & 17.96 \\
\hline
\end{tabular}

The differentiation of the surface roughness was achieved by means of mechanical treatment - grinding $\left(R_{\mathrm{a}}=0.60 \mu \mathrm{m}\right)$ and mechanical polishing $\left(R_{\mathrm{a}}=0.14 \mu \mathrm{m}\right)$. Chemical passivation was made in $\mathrm{HNO}_{3} 40 \%$. Next, the samples were subjected to sterilisation with ethylene oxide. The sterilisation was performed at the temperature of $55{ }^{\circ} \mathrm{C}$ in a Steri-Vac $5 \mathrm{XL}$ steriliser. Before the tests, all the samples were cleaned in ethanol $96 \%$ in an ultrasonic disintegrator. Next, the samples corresponding to the consecutive stages of the surface preparation were tested for the resistance to pitting corrosion. The tests were carried out in accordance with ASTM. ${ }^{8,9}$ Polarisation curves were registered by means of potentiostat PGP-201 by Radiometer. A saturated calomel electrode (SCE) of the KP-113 type was used as the reference electrode. A platinum electrode of the PtP-201 type served as the auxiliary electrode. The change in the potential in the anodic direction took place at the rate of $1 \mathrm{mV} / \mathrm{s}$. Once the current density reached the value of $1 \mathrm{~mA} / \mathrm{cm}^{2}$, the polarisation direction was changed and, at the same time, a return curve was registered. The tests were made in an alternative solution simulating a human-blood environment - in an artificial-blood plasma. The chemical composition of the artificial-blood plasma is presented in Table 2. The temperature of the artificial-blood plasma during the tests was $(37 \pm 1){ }^{\circ} \mathrm{C}$ and $\mathrm{pH}=7 \cdot 2 \cdot{ }^{10,11}$ The Stern method was applied for determining the parameters typical of the corrosion resistance of the tested alloys.

Table 2: Chemical composition of artificial plasma

Tabela 2: Kemijska sestava umetne plazme

\begin{tabular}{|c|c|}
\hline Component & Amount in distilled water g/L \\
\hline $\mathrm{NaCl}$ & 6.8 \\
\hline $\mathrm{CaCl}_{2}$ & 0.2 \\
\hline $\mathrm{KCl}$ & 0.4 \\
\hline $\mathrm{MgSO}_{4}$ & 0.1 \\
\hline $\mathrm{NaHCO}_{3}$ & 2.2 \\
\hline $\mathrm{Na}_{2} \mathrm{HPO}_{4}$ & 0.126 \\
\hline $\mathrm{NaH}_{2} \mathrm{PO}_{4}$ & 0.026 \\
\hline & \\
\hline
\end{tabular}

XPS (X-ray photoelectron spectroscopy) was applied for identifying the chemical composition of the sample surface layer before and after the chemical-passivation process and sterilization in ethylene oxide. A photoelectron spectrometer made by Prevac with an analyser and monochromatic X-ray source by VG Scienta were used. Photoelectrons were activated with an X-ray tube with an aluminium anode and a quartz monochromator that ensured the $\mathrm{Al} K_{\alpha}$ radiation with an energy of 1486.6 $\mathrm{eV}$. The spectra in a wide range of electron bond energy as well as detailed spectra with high resolution made as in-depth profiles were tested. Ion etching was performed with $\mathrm{Ar}^{+}$ions with an energy of $4 \mathrm{keV}$. The analysed area was rectangular with the following dimensions: $260 \mu \mathrm{m}$ $\times 1000 \mu \mathrm{m}$, with the longer side parallel to the axis of the samples. The ion-etching area was $2000 \mu \mathrm{m} \times 2000 \mu \mathrm{m}$, which ensured a safe distance from the edge of the crater created as a result of the argon-ion bombardment of the surface. The chemical composition was determined by integrating the respective photoemission lines with the application of programme MULTIPAK by Physical Electronics.

Table 3: Potentiodynamic-test results for X10CrNi18-8 steel

Tabela 3: Rezultati potenciodinamičnih preizkusov na jeklu X10CrNi18-8

\begin{tabular}{|c|c|c|c|c|}
\hline Surface type & $\begin{array}{l}\text { Corrosion potential } \\
\qquad E_{\text {corr }} / \mathrm{mV}\end{array}$ & $\begin{array}{l}\text { Breakdown potential } \\
\qquad E_{\mathrm{b}} / \mathrm{mV}\end{array}$ & $\begin{array}{c}\text { Polarisation resistance } \\
\text { (average) } \\
R_{\mathrm{p}} /\left(\mathrm{k} \Omega \mathrm{cm}^{2}\right)\end{array}$ & $\begin{array}{c}\text { Corrosion current density } \\
\text { (average) } \\
i_{\text {corr. }} /\left(\mu \mathrm{A} / \mathrm{cm}^{2}\right)\end{array}$ \\
\hline \multicolumn{5}{|c|}{ Before EO } \\
\hline Polished & -63 to -55 & +377 to +383 & 229 & 0.114 \\
\hline Passivated & +15 to +25 & +690 to +700 & 1070 & 0.024 \\
\hline \multicolumn{5}{|c|}{ After EO } \\
\hline Polished & -81 to -71 & +520 to +560 & 1060 & 0.025 \\
\hline Passivated & -72 to -63 & +790 to +830 & 2470 & 0.010 \\
\hline
\end{tabular}




\section{RESULTS AND DISCUSSION}

The performed potentiodynamic tests in the artificial-blood plasma supplied the information regarding the corrosion resistance of austenitic steel X10CrNi18-8 with its surface prepared in different ways and subjected to the sterilisation process. Potentiodynamic-test results are presented in Table 3. Anodic-polarisation curves are shown in Figure 1.

It was determined that the average corrosion-potential value for the wire subjected to electrochemical polishing was lower $\left(E_{\text {corr }}=-59 \mathrm{mV}\right)$ than that obtained for the wire subjected to chemical passivation $\left(E_{\text {corr }}=\right.$ $+20 \mathrm{mV}$ ). The mean values of the perforation potential and possible repassivation, determined on the ground of the registered polarisation curves, were also lower for the wire subjected to polishing. It was also proved that there were significant differences between the determined values of corrosion-current density $i_{\text {corr }}$ and polarisation resistance $R_{\mathrm{p}}$ (Figure $\mathbf{1}$ and Table $\mathbf{3}$ ).

In order to identify the chemical composition of the surface layer created as the result of the electrochemical treatment and sterilisation process, XPS tests were performed. An analysis of the spectral lines for the respective elements enabled us to draw the conclusions
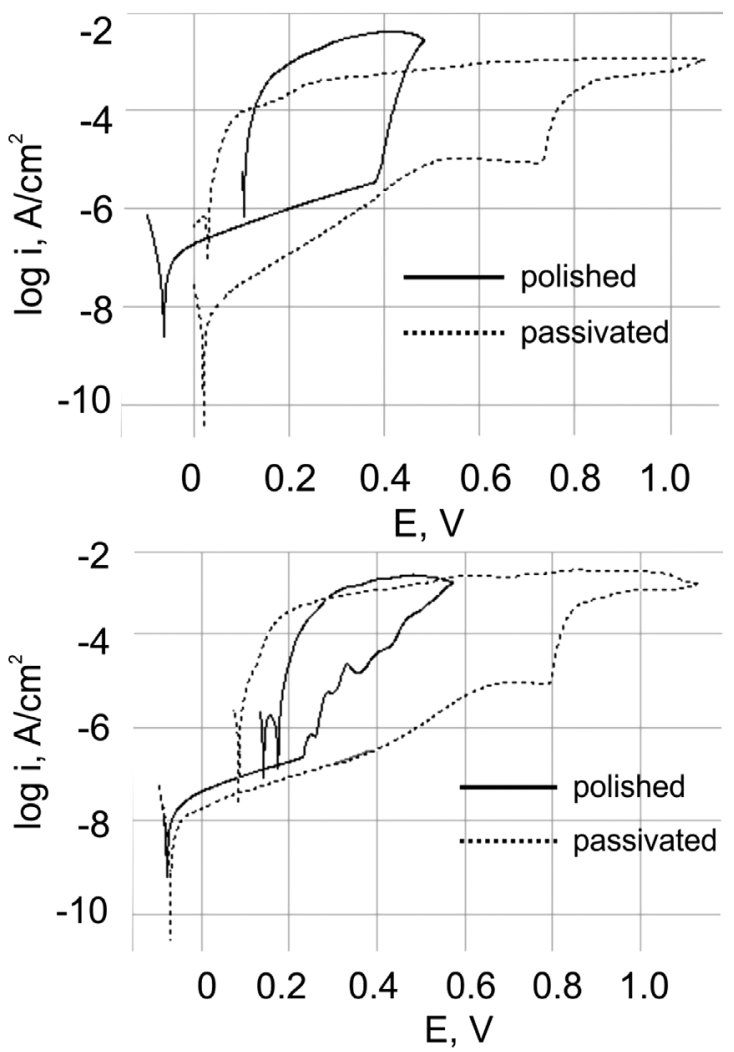

Figure 1: Polarisation curves determined for X10CrNi18-8 steel after electrochemical surface treatment: a) before sterilisation in ethylene oxide, b) after sterilisation in ethylene oxide

Slika 1: Polarizacijske krivulje, ugotovljene pri jeklu X10CrNi18-8 po elektrokemijski obdelavi površine: a) pred sterilizacijo v etilen oksidu, b) po sterilizaciji v etilen oksidu
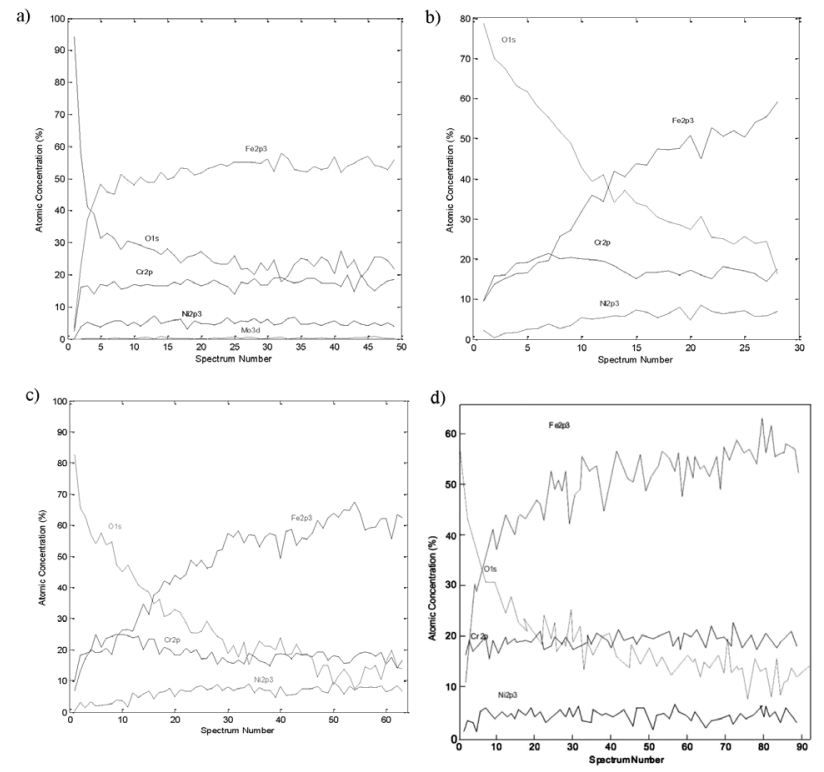

Figure 2: In-depth profiles registered for X10CrNi18-8 steel after the processes of: a) electrochemical polishing, b) electrochemical polishing and sterilisation in ethylene oxide, c) chemical passivation, d) chemical passivation and sterilisation in ethylene oxide

Slika 2: Profil koncentracije v globino pri jeklu X10CrNi18-8 po: a) elektrokemijskem poliranju, b) elektrokemijskem poliranju in sterilizaciji z etilen oksidom, c) kemijski pasivaciji, d) kemijski pasivaciji in sterilizaciji $\mathrm{z}$ etilen oksidom

regarding their chemical states and their changes depending on the depth of the analysed layer (Figure 2). The bond energy of electron states depends on the chemical compound, in which an element is present. A favourable decrease in the main alloying elements of $\mathrm{Fe}$, $\mathrm{Cr}$ and $\mathrm{Ni}$ in relation to the substrate, as well as an increase in the participation of oxide compounds of those
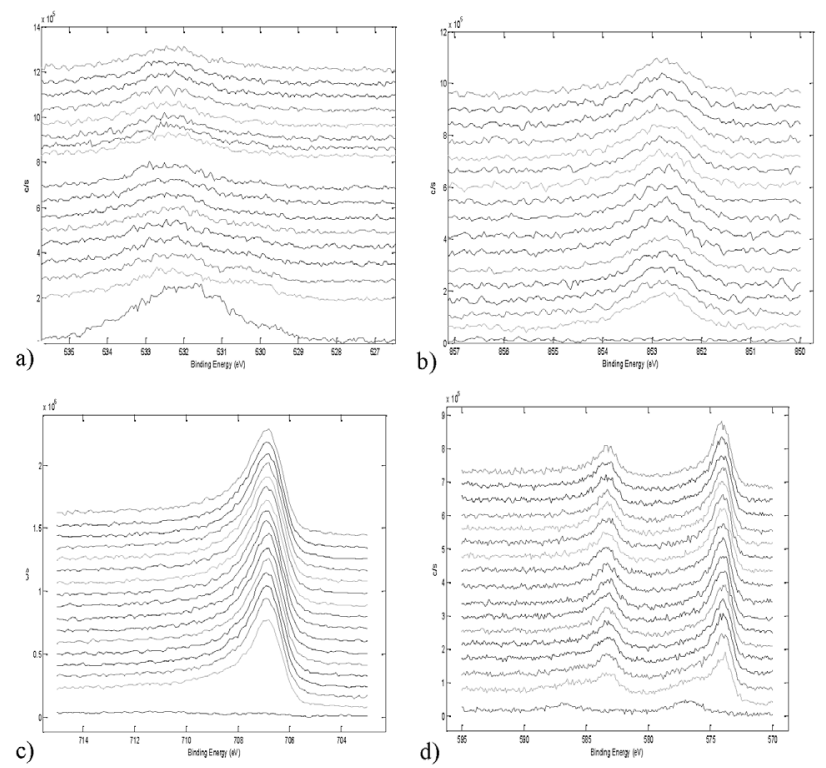

Figure 3: XPS spectra of $\mathrm{X} 10 \mathrm{CrNi} 18-8$ steel for lines (electrochemical polishing): a) O1s, b) Ni2p3/2, c) Fe2p3/2, d) Cr2p

Slika 3: XPS-spektri za jeklo $\mathrm{X} 10 \mathrm{CrNi} 18-8$ za linije (elektrokemijsko poliranje): a) $\mathrm{O} 1 \mathrm{~s}$, b) $\mathrm{Ni} 2 \mathrm{p} 3 / 2$, c) $\mathrm{Fe} 2 \mathrm{p} 3 / 2$, d) $\mathrm{Cr} 2 \mathrm{p}$ 

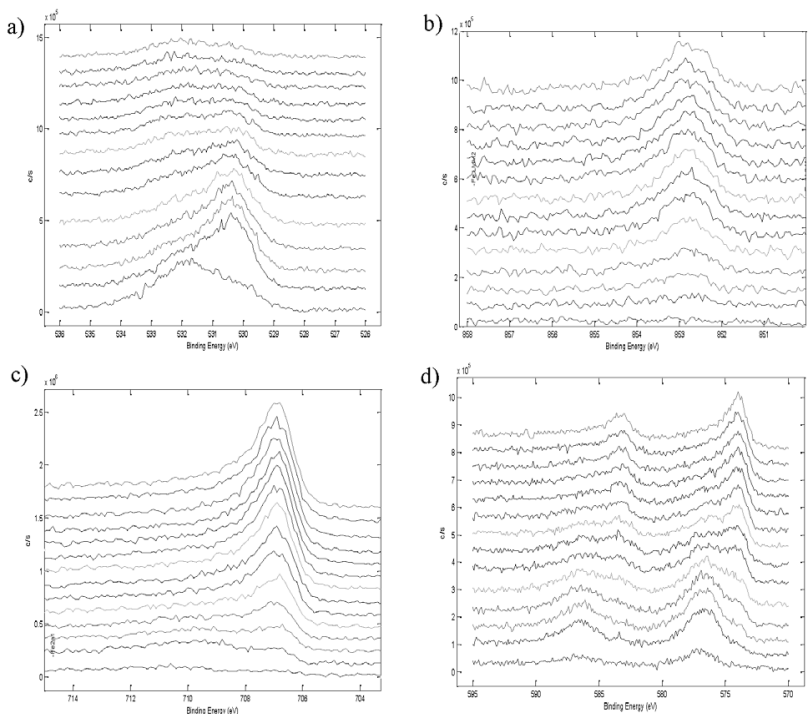

Figure 4: XPS spectra of X10CrNi18-8 steel for lines (electrochemical polishing and sterilisation in ethylene oxide): a) $\mathrm{O} 1 \mathrm{~s}, \mathrm{~b}$ ) $\mathrm{Ni} 2 \mathrm{p} 3 / 2$, c) Fe2p3/2, d) Cr2p

Slika 4: XPS-spektri za jeklo X10CrNi18-8 za linije (elektrokemijsko poliranje in sterilizacija $\mathrm{z}$ etilen oksidom): a) $\mathrm{O} 1 \mathrm{~s}$, b) $\mathrm{Ni} 2 \mathrm{p} 3 / 2$, c) $\mathrm{Fe} 2 \mathrm{p} 3 / 2$, d) $\mathrm{Cr} 2 \mathrm{p}$

elements were detected in the composition of the passive layer obtained after the electrochemical treatment and sterilisation in ethylene oxide (Figures 3 to 6). Oxide compounds feature better haemocompatibility. Measured line O1s may be subordinate to several chemical states. The main line with the energy of $285.29 \mathrm{eV}$ could be assigned to hydrocarbons, ever present on the surface. A weak line with the maximum energy of $283.50 \mathrm{eV}$ that came from carbides, e.g., $\mathrm{Cr}_{3} \mathrm{C}_{2}$, was also visible. Other weak lines at their maximum levels, with their energy
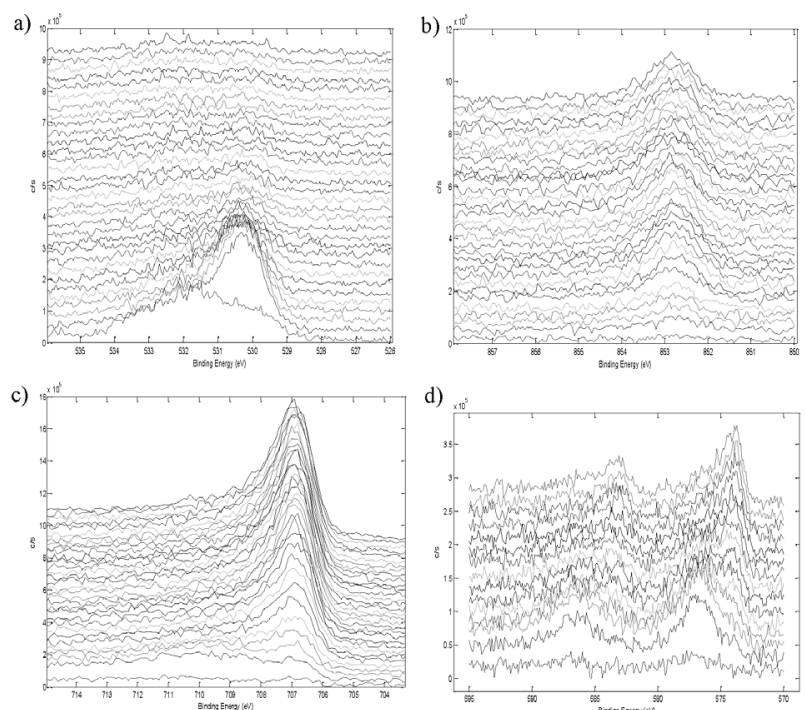

Figure 5: XPS spectra of X10CrNi18-8 steel for lines (chemical passivation): a) O1s, b) Ni2p3/2, c) $\mathrm{Fe} 2 \mathrm{p} 3 / 2$, d) Cr2p

Slika 5: XPS-spektri za jeklo X10CrNi18-8 za linije (kemijska pasivacija): a) $\mathrm{O} 1 \mathrm{~s}$, b) $\mathrm{Ni} 2 \mathrm{p} 3 / 2$, c) $\mathrm{Fe} 2 \mathrm{p} 3 / 2$, d) $\mathrm{Cr} 2 \mathrm{p}$ slightly higher than $285.30 \mathrm{eV}$ could be attributed to the organic compounds containing oxygen or the carbonates created during the surface treatment of the sample. With respect to analysing the Fe spectrum, two chemical states are visible: metallic $\mathrm{Fe}(707 \mathrm{eV})$ and the form of oxide, $\mathrm{Fe}_{2} \mathrm{O}_{3}(711 \mathrm{eV})$, which may be determined through a comparison with the spectra of the respective iron oxides and an analysis of the satellites, e.g., $719 \mathrm{eV}$ - the typical position of $\mathrm{Fe}_{2} \mathrm{O}_{3} .{ }^{12}$ For chromium, the oxidized condition was dominant; line $\mathrm{Cr} 2 \mathrm{p}_{3 / 2}$ with an energy of $577.0 \mathrm{eV}$ was emitted by $\mathrm{Cr}_{2} \mathrm{O}_{3}$, whereas the weak line with an energy of $574.4 \mathrm{eV}$ was emitted by metallic chromium. The line of oxygen included various chemical states. The line with an energy of about $531.6 \mathrm{eV}$, which could be attributed to $\mathrm{Cr}_{2} \mathrm{O}_{3}$, was dominant. ${ }^{13}$ For the transition metals, such as chromium or nickel, the effect of the reduction due to the ion bombardment was taken into consideration. This effect is particularly important when interpreting the nickel spectra. Nickel oxides are largely reduced due to the ions with an energy of $4 \mathrm{keV}$. The absence of nickel oxides in the spectra may just partially result from this effect (Table 4).

Table 4: Results of XPS analyses

Tabela 4: Rezultati XPS-analiz

\begin{tabular}{|c|c|c|c|c|c|}
\hline \multirow{2}{*}{$\begin{array}{c}\text { Surface } \\
\text { type }\end{array}$} & \multicolumn{5}{|c|}{ Elements in amount fractions, $x / \%$} \\
\cline { 2 - 6 } & $\mathrm{O}$ & $\mathrm{C}$ & $\mathrm{Fe}$ & $\mathrm{Cr}$ & $\mathrm{Ni}$ \\
\hline \multicolumn{7}{|c|}{ Before EO } \\
\hline Polished & 35.16 & 52.05 & 7.61 & 5.17 & - \\
\hline Passivated & 55.11 & 41.21 & 2.23 & 1.03 & 0.41 \\
\hline \multicolumn{7}{|c|}{ After EO } \\
\hline Polished & 34.55 & 50.23 & 9.29 & 5.92 & - \\
\hline Passivated & 60.76 & 33.25 & 3.25 & 3.52 & 0.21 \\
\hline
\end{tabular}
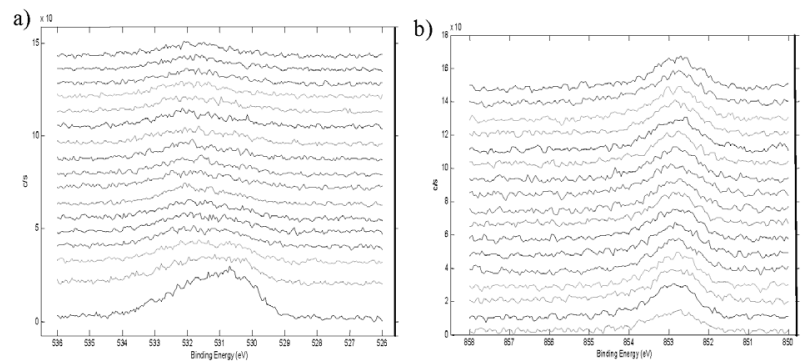

c)
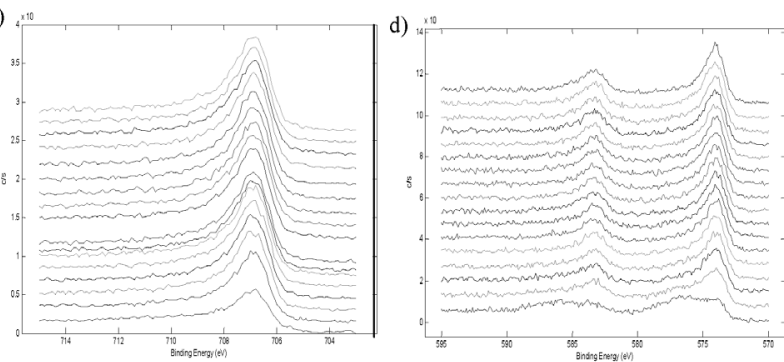

Figure 6: XPS spectra of $\mathrm{X} 10 \mathrm{CrNi18}-8$ steel for lines (chemical passivation and sterilisation in ethylene oxide): a) $\mathrm{O} 1 \mathrm{~s}$, b) $\mathrm{Ni} 2 \mathrm{p} 3 / 2$, c) $\mathrm{Fe} 2 \mathrm{p} 3 / 2$, d) Cr2p

Slika 6: XPS-spektri za jeklo X10CrNi18-8 za linije (kemijska pasivacija in sterilizacija $\mathrm{z}$ etilen oksidom): a) $\mathrm{O} 1 \mathrm{~s}$, b) $\mathrm{Ni2p} 3 / 2$, c) $\mathrm{Fe} 2 \mathrm{p} 3 / 2$, d) $\mathrm{Cr} 2 \mathrm{p}$ 


\section{CONCLUSIONS}

An innovative progress in treating cardiovascularsystem diseases using low-invasive methods led to the production of new forms of tools, such as guide wires. Those tools, introduced as the first ones to a narrowed section of a blood vessel, many times increase its crosssection in a situation of its total closure. Some limitations, observed in the clinical practice, resulting from the introduction of the tools made of metallic materials to blood vessels, are mainly connected with the blood coagulation on their surfaces. ${ }^{14}$ Therefore, the study contains an evaluation of the impact of the surface treatment that enables us to increase the biotolerance of the $\mathrm{X} 10 \mathrm{CrNi18-8}$ steel in a blood environment under the conditions of sterilisation with ethylene oxide.

The analysis of the results of the electrochemicalcorrosion tests proved differentiated corrosion resistance of the wires made of the $\mathrm{X} 10 \mathrm{CrNi} 18-8$ steel. Less favourable values of the determined parameters that characterise the corrosion resistance result from restricting their surface treatment only to polishing (Table 3).

Next, the in-depth profiles obtained for individual variants of the surface treatment showed that electrochemical polishing, chemical passivation and sterilisation in ethylene oxide caused an increase in the oxygen in the surface layer in relation to the substrate, mainly resulting in the oxides such as: $\mathrm{Cr}_{2} \mathrm{O}_{3}$ and $\mathrm{Fe}_{2} \mathrm{O}_{3}$. Consequently, the concentrations of individual alloying elements $(\mathrm{Fe}$, $\mathrm{Cr}, \mathrm{Ni}$ ) in relation to the chemical composition of the substrate were substantially decreased, which is found to be extremely favourable for the haemocompatibility of guide wires. All the elements occurred mainly in the oxidised condition.

To sum up, it must be stated that the chemical-passivation process performed after electrochemical polishing of the X10CrNi18-8 steel has a favourable impact on the physical and chemical characteristics, improving the haemocompatibility of the cardiologic guide wires made of this type of steel.

\section{Acknowledgements}

This project was financed from the funds of the National Science Centre in Cracow.

\section{REFERENCES}

${ }^{1}$ M. Kaczmarek, W. Walke, W. Kajzer, Arch. Mater. Sci. Eng., 28 (2007) 5, 273-276

${ }^{2}$ J. Marciniak, J. Tyrlik-Held, W. Walke, Z. Paszenda, Eng. of Biomat., X (2007) 69-72, 90-93

${ }^{3}$ D. Baim, W. Grossman, Angiography and Intervention, $6^{\text {th }}$ edition, LWW, Philadelphia 2000

${ }^{4}$ D. Baim, W. Grossman, Angiography and Intervention, $7^{\text {th }}$ edition, LWW, Philadelphia 2006

${ }^{5}$ M. Dewey, F. Teige, D. Schnapauff, Ann. of Int. Med., 145 (2006) 6, 407-415, doi:10.7326/0003-4819-145-6-200609190-00004

${ }^{6}$ W. Walke, J. Przondziono, Metalurgija, 50 (2011) 3, 201-204

${ }^{7}$ W. Walke, J. Przondziono, Arch. of Metall. and Mat., 58 (2013) 2, 625-630, doi:10.2478/amm-2013-0048

${ }^{8}$ ASTM F2129-08 Standard Practice for Selecting Generic Biological Test Methods for Materials and Devices, 2008

${ }^{9}$ ASTM F746-04(2009): Standard Test Method for Pitting or Crevice Corrosion of Metallic Surgical Implant Materials, 2009

${ }^{10}$ J. Marciniak, J. Tyrlik-Held, W. Walke, Z. Paszenda, Arch. Mater. Sci. Eng., 28 (2007) 5, 289-292

${ }^{11}$ W. Kajzer, A. Krauze, W. Walke, J. Marciniak, J. Achiev. Mat. Manuf. Eng., 18 (2006), 115-118

${ }^{12}$ C. R. Clayton, Y. C. Lu, J. Electrochem. Soc., 133 (1986) 12, 2465-2473, doi:10.1149/1.2108451

${ }^{13}$ J. M. Grimal, P. Marcus, Corr. Sci., 5 (1992), 805-814, doi:10.1016/ 0010-938X(92)90113-H

${ }^{14}$ A. Tortoriello, G. Pedrizzetti, J. of Biomech., 37 (2004), 1-11, doi:10.1016/S0021-9290(03)00259-8 